\title{
HORIZONTAL DIRECT EFFECT OF THE CHARTER IN EU LAW: RAMIFICATIONS FOR THE EUROPEAN ECONOMIC AREA
}

\author{
GRAHAM BUTLER* \& MARIUS MELING ${ }^{\dagger}$
}

\begin{abstract}
In a consistent line of jurisprudence, the Court of Justice of the European Union (CJEU) bas now stated that, as a last resort, provisions of the EU Charter of Fundamental Rights (the Charter) can have horizontal direct effect. More specifically, this possibility occurs when a provision of the Charter has been given specific expression to from a directive. Whilst it has long been the case that directives in themselves continue to not have horizontal direct effect in EU law, there is no doubting that the horizontal direct effect of provisions of the Charter, which in turn are given specific expression to from a directive, is increasingly being found. This possibility of borizontal direct effect of the Charter is of striking significance for European Economic Area (EE A) law for two reasons. Firstly, there is no doctrine of direct effect in $E E A$ law according to the European Free Trade Association (EFTA) Court; and secondly, the Charter is not incorporated into EFTA pillar of EE $A$ law in any way. Given the potential for the widening divergence between $E U$ law and EEA law on the existence of horizontal direct effect of the Charter when given specific expression to from a directive, with a homogeneity gap opening up, this article considers the ramifications for the EE $A$ of such advances in $E U$ law, and proposes some solutions for how these $\mathrm{EU}$ legal developments can be responded to within $\mathrm{EE} A$ law.
\end{abstract}

\section{INTRODUCTION}

Argument and debate concerning the horizontal direct effect of EU law are as old as the hills. However, new developments, such as the potential of horizontal direct effect of the EU Charter of Fundamental Rights (the Charter), when given specific expression to from a directive, represent an opportunity to understand these changes brought on by a line of case law from the Court of Justice of the European Union (CJEU), but also, in turn, see how they will have an impact on EEA law, and the jurisprudence of the European Free Trade Association (EFTA) Court. In a string of recent cases such as Egenberger, ${ }^{1}$ Bauer, ${ }^{2}$ and Cresco Investigation, ${ }^{3}$ and others, the CJEU has confirmed that horizontal direct effect of the Charter is possible in EU law, when a provision of the Charter is given effect to, or given specific expression to from a directive. The horizontal direct effect of the Charter has long been

\footnotetext{
* Associate Professor of Law, Aarhus University, Denmark.

† Higher Executive Officer, Norwegian Agency for Public and Financial Management (Direktoratet for forvaltning og økonomistyring (DFØ)), Stavanger, Norway. The authors wish to thank the anonymous reviewer for their comments. All views remain are those of the authors alone.

${ }^{1}$ Case C-414/16, Vera Egenberger v Evangelisches Werk für Diakonie und Entwicklung e.V., ECLI:EU:C:2018:257.

${ }^{2}$ Case C-569/16, Stadt Wuppertal v Maria Elisabeth Bauer and Volker Willmeroth v Martina Broßonn, ECLI:EU:C:2018:871.

${ }^{3}$ Case C-193/17, Cresco Investigation GmbH v Markus Achatzi, ECLI:EU:C:2019:43.
} 
predicted to be a possibility, ${ }^{4}$ and such a prediction is now seeing its validation on a case-bycase, article-by-article basis.

These developments in the case law of the CJEU will not only have an effect on the manner in which EU law is applied in EU Member States, ${ }^{5}$ but rather, it will also have ramifications that extend to EEA law, as applied in Iceland, Liechtenstein, and Norway - the three EFTA states applying the EEA Agreement, at least as far as directives are concerned. Why horizontal direct effect of the Charter in EU law, when given specific expression to from a directive, is of particular interest to EEA law is that the issue of direct effect, more generally, which has long been a feature of EU law, is not completely straightforward, because direct effect is not a doctrine in EEA law. Instead, the main remedy for individuals in EEA law is state liability, as confirmed by the EFTA Court in Sveinbjörnsdóttir, ${ }^{6}$ which has mimicked the initial Francovich doctrine from EU law. ${ }^{7}$ With this new line of case law from the CJEU that has allowed for the horizontal direct effect of the Charter when given specific expression to from a directive, this has in turn reduced the value of the doctrine of state liability in EU law as a remedy; which by contrast in EEA law, is the main remedy.

In EU law, direct effect and state liability are distinctly separated measures, providing different solutions to what is often the same problem - the effectiveness of EU law (or lack thereof) within EU Member States. Direct effect allows a non- or incorrectly implemented EU provision to take precedence over conflicting national law in a given situation; whilst state liability affords the possibility for compensation provided by the state towards those who have suffered a loss as a consequence of the state's failure to comply with the provisions in question. With the horizontal direct effect of the Charter, when given specific expression to from a directive now coming into place as a result of new CJEU case law, this reduces the state liability doctrine in EU law to a mere safety net, when other remedies cannot come into play.

Prior to this recent jurisprudence in EU law, case like Egenberger and others would have been solved in EU law through state liability, thus making the applicable EU Member State liable for not fulfilling its obligations under EU law to properly implement a directive. In confirming that provisions of the Charter may have horizontal direct effect when given specific expression to from a directive, such a turn in the CJEU case law potentially places the consequences of non- or incorrectly implemented directives onto private actors, as opposed to EU Member States. By contrast, there is no horizontal direct effect in EEA law, and EEA law is exclusively dependent on state liability as the main remedy to ensure the effectiveness of EEA law, which is a major difference from the role of state liability in EU law.

\footnotetext{
${ }^{4}$ For this perspective, see, Xavier Groussot, 'Direct Horizontal Effect in EU Law after Lisbon - The Impact of the EU Charter of Fundamental Rights on Private Parties' in Patrik Lindskoug and others (eds), Essays in Honour of Michael Bogdan (Juristförlaget 2013).

${ }^{5}$ For extensive analysis of horizontal effect of fundamental rights, see, Eleni Frantziou, The Horizontal Effect of Fundamental Rights in the European Union: A Constitutional Analysis (Oxford University Press 2019); Sonya Walkila, Horizontal Effect of Fundamental Rights in EU Law (Europa Law Publishing 2016).

${ }^{6}$ Case E-9/97, Erla María Sveinbjörnsdóttir v Iceland, Advisory Opinion (Judgment) of the EFTA Court, 10

December 1998.

${ }^{7}$ Joined Cases C-6/90 and C-9/90, Andrea Francovich and Danila Bonifaci and others $v$ Italian Republic, ECLI:EU:C:1991:428.
} 
This article sets forth the premise that with the possibility of horizontal direct effect of the Charter in EU law, when given specific expression to from a directive, which de facto gives selective horizontal direct effect of directives (but not the directives themselves, but rather by way of the Charter, which can have horizontal direct effect), EFTA states applying the EEA Agreement have a varied form of fundamental rights protection, with a lower form of protection when compared to EU Member States, given the CJEU's new line of jurisprudence. Thus, with a potential higher level of protection afforded to individuals and economic operators in EU Member States, this poses significant issues for EEA law, which strives for a homogenous application of the internal market framework and accompanying law. Accordingly, this article considers the ramifications this new strand of CJEU case law has on EEA law, given two distinct differences between EU law and EEA law - firstly, the absence of the doctrine of direct effect; and secondly, the formal absence of the Charter in EEA law.

Five modest options are set forth with regard to what can be done in EEA law about these new constitutional developments in the EU legal order. Option 1 considers continuance of state liability in EEA law without direct effect, following the limited interpretation of state liability in EU law, without doing anything regarding direct effect, thus widening the gap between EU law and EEA law. Option 2 contemplates extending the doctrine of state liability to cover situations where there is direct effect in the EU legal order, making the EFTA state further liable in EEA law than would otherwise be for Member States in EU law. Option 3 envisions the EFTA Court affirmatively embracing the Charter in EEA law, and opening up for horizontal direct effect of the Charter when it is given specific expression to from a directive, in the same manner that the CJEU has recently been doing in EU law. Option 3 would therefore be maintaining full homogeneity and equivalent rights protection between EU law and EEA law. Option 4 anticipates the EFTA Court doing nothing at all, and continue to allow the gap between EU law and EEA law grow larger, thus not giving due consideration to the principle of homogeneity in EEA law. Lastly, option 5 would see the national legal orders incorporate fundamental principles of EU law arising from the Charter, and apply them as national law, without the involvement of EEA law. As this article contends, these are the most likely, but by no mean definitive outcomes within EEA law that will be seen in the future.

The article is structured as follows. Section 2 sets the doctrine of direct effect in EU law, and how horizontal direct effect of different EU legal instruments are understood. Section 3 then goes on to examine the most recent case law of the CJEU that has confirmed, in certain circumstances, the horizontal direct effect of the Charter, when given specific expression to from a directive. Section 4 elaborates on how direct effect has been handled in EEA law, and the way in which it has been interpreted by the EFTA Court, in addition to analysing the doctrine of state liability as the main remedy in EEA law. In light of the differences between EU law and EEA law that become apparent from the analysis contained in sections 2, 3, and 4, the following section 5 discusses how the recent developments in EU law concerning the potential for the horizontal direct effect of the Charter, when given specific expression to from a directive, would be handled as a matter of EEA law. Five different options are therefore contemplated for how EEA responds to such developments in EU law. Section 6 thereafter evaluates the various options that should be considered by 
actors in the EEA legal order, before section 7 concludes with some closing observations and reflections on the relationship between EU law and EEA law in the future.

\section{DIRECT EFFECT AND HORIZONTAL DIRECT EFFECT IN EU LAW}

In a broad sense, the doctrine of direct effect means that provisions of EU law that are sufficiently clear, precise, and unconditional to be considered justiciable can be invoked and relied on by individuals before national courts. Vertical direct effect concerns the rights that an individual has against an EU Member State, while horizontal direct effect is when an individual has a right or an obligation against another individual. As far back as when the doctrine of direct effect (at least as regard provisions of the EU treaties) was uncovered in $V$ an Gend en Loos, the horizontal dimension of the doctrine of direct effect was already foreseen. As put by the CJEU, EU law 'not only imposes obligations on individuals but is also intended to confer upon them rights, ${ }^{8}$ even if horizontal direct effect was not relevant to the case at hand.

The difference between vertical and horizontal direct effect may be the 'classic' way to frame the direct effect saga in EU law, yet it is an important one. Despite the prominence of the doctrine of direct effect in EU law, the case law on the horizontal direct effect with regard to EU primary law is rather minimal in nature. Only select provisions have been given such treatment by the CJEU, such as in Defrenne II, ${ }^{10}$ Angonese, ${ }^{11}$ Martinez Sala, ${ }^{12}$ and Viking Line. ${ }^{13}$ The main centre of interest on direct effect in EU law, therefore, has been on direct effect of EU secondary law, namely and in particular, directives. The doctrine of direct effect was extended to cover directives in vertical situations in Van Duyn, ${ }^{14}$ but left open the horizontal aspect of the doctrine. This is because such horizontal application of the doctrine posed much more difficult questions for how EU law was to be effective in EU Member States, and how remedies were to be ensured. ${ }^{15}$

The distinction of vertical and horizontal direct effect of directives, and whether the latter was possible, later arose in Marshall $I,{ }^{16}$ where the CJEU found that a directive in itself may not impose obligations on individuals. This was the beginning of the CJEU's longstanding answer to the questions surrounding horizontal direct effect of directives, which

\footnotetext{
${ }^{8}$ Case C-26/62, NV Algemene Transport- en Expeditie Onderneming van Gend \& Loos v Netherlands Inland Revenue Administration, ECLI:EU:C:1963:1, p.12.

9 'Takis Tridimas, 'Black, White, and Shades of Grey: Horizontality of Directives Revisited' (2001) 21

Yearbook of European Law 327, 328.

${ }^{10}$ Case C-43/75, Gabrielle Defrenne v Société anonyme belge de navigation aérienne Sabena, ECLI:EU:C:1976:56

('Defrenne II'), in Article 157 TFEU.

${ }^{11}$ Case C-281/98, Roman Angonese v Cassa di Risparmio di Bolzano SpA, ECLI:EU:C:2000:296, on Article 45 TFEU.

12 Case C-85/96, María Martínez. Sala v Freistaat Bayern, ECLI:EU:C:1998:217, on Article 18 TFEU.

${ }^{13}$ Case C-438/05, International Transport Workers' Federation and Finnish Seamen's Union v Viking Line ABP and OÜ Viking Line Eesti, ECLI:EU:C:2007:772, on Article 49 TFEU.

${ }_{14}$ Case C-41/74, Yvonne van Duyn v Home Office, ECLI:EU:C:1974:133, para 7.

${ }^{15}$ For a thorough background, see, Deirdre Curtin, 'The Province of Government: Delimiting the Direct Effect of Directives in the Common Law Context' (1990) 15 European Law Review 195.

${ }^{16}$ Case C-152/84, M. H. Marshall v Southampton and South-West Hampshire Area Health Authority (Teaching), ECLI:EU:C:1986:84 ('Marshall I').
} 
was 'famously', ${ }^{17}$ and affirmatively - no. According to the CJEU, since directives were specifically addressed to the Member States, these could not impose obligations on individuals. Notably, the Opinion of the Advocate General in Marshall I stated that 'horizontal direct effect would totally blur the distinction between directives and regulations. ${ }^{18}$ This point, effectively endorsed by the CJEU by denying horizontal direct effect of directives, has remained a factor and thus reappeared as grounds for reasoning in later cases. ${ }^{19}$ Several Advocates General have taken an alternative view of Advocate General Slynn and the CJEU since, ${ }^{20}$ but to no avail of changing the CJEU's perspective, and the lack of horizontal direct effect of directives, in themselves, has remained the stated position of the CJEU. The reasons that have been offered by the CJEU through its extensive case law that there should be no horizontal direct effect of directives is that directives are only binding on those to whom it is addressed, the Member States; that it prevents those Member States from opportunistically not implementing a directive; that the lack of horizontal direct effect maintains the distinction between regulations and directives; and that legal certainty dictates a consistent position of the CJEU. ${ }^{21}$ Recently in Smith, the CJEU again repeated its mantra on the lack of horizontal direct effect of directives in themselves. ${ }^{22}$ Yet that did not mean that there was no horizontal direct effect in EU law, as this had been known to be possible since Defrenne II with regard to provision of EU primary law. There, it was stated that Article 157 TFEU on the prohibition on gender discrimination also applies to the relationship between individuals, and not just against states or functions operating as the state. ${ }^{23}$ Therefore, horizontal direct effect of EU law was potentially possible, but under uncertain circumstances. As a result, as a general rule, the question of horizontal direct effect was not a question of whether it was possible, but when it was so.

In Egenberger, Bauer, and Cresco Investigation, and subsequent cases, a noted shift occurred in regard to the horizontal direct effect in EU law, not as a result of the CJEU changing its view itself, but because of the effect of the Charter, when given specific expression to from a directive. This is in line with the long-standing position that if horizontal direct effect of directives was to be denied, then it was 'imperative to consider other possibilities [that EU] law offers by way of alternative remedies'. ${ }^{24}$ Horizontality of EU law, today, comes in many ways. The horizontal application of direct effect turns the addressee of a directive from just the state, however widely drawn, to being pointed at everyone in an indiscriminate fashion.

\footnotetext{
${ }^{17}$ Robert Schütze, 'Direct Effects and Indirect Effects of Union Law' in Robert Schütze and Takis Tridimas (eds), Oxford Principles of European Union Law, vol 1: The European Union Legal Order (Oxford University Press 2018), 279.

18 Opinion of Advocate General Slynn, Case C-152/84, M. H. Marshall v Southampton and South-West Hampshire Area Health Authority (Teaching), ECLI:EU:C:1985:345 ('Marshall I'), 734.

${ }^{19}$ For example, in Case C-91/92, Paola Faccini Dori v Recreb Srl, ECLI:EU:C:1994:292.

20 Opinion of Advocate General Van Gerven, Case C-271/91, M. Helen Marshall v Southampton and South-West Hampshire Area Health Authority, ECLI:EU:C:1993:30 ('Marshall II); Opinion of Advocate General Jacobs, Case C-316/93, Nicole Vaneetveld v Le Foyer $S A$ and Le Foyer $S A v$ Fédération des Mutualités Socialistes et Syndicales de la Province de Liège, ECLI:EU:C:1994:32; Opinion of Advocate General Lenz, Case C-91/92, Paola Faccini Dori v Recreb Srl, ECLI:EU:C:1994:45; Opinion of Advocate General Sharpston, Case C-413/15, Elaine Farrell $v$ Alan Whitty and Others, ECLI:EU:C:2017:492.

${ }^{21}$ Case C-201/02, The Queen, on the application of Delena Wells v Secretary of State for Transport, Local Government and the Regions, ECLI:EU:C:2004:12, para 56.

22 Case C-122/17, David Smith v Patrick Meade and Others, ECLI:EU:C:2018:631, para 42.

${ }^{23}$ Case C-43/75, Gabrielle Defrenne v Société anonyme belge de navigation aérienne Sabena, ECLI:EU:C:1976:56 ('Defrenne $I T$ ').

${ }^{24}$ Sacha Prechal, 'Remedies After Marshall’ (1990) 27 Common Market Law Review 451, 473.
} 
Through the Charter, but upon reliance on a directive, which gives certain rights under the Charter specific expression, is a new way in which horizontal direct effect is manifesting itself in EU law. In EU law, the question is no longer on whether the Charter is horizontally applicable, but on which parts of the Charter are capable of having horizontal direct effect.

\section{HORIZONTAL DIRECT EFFECT OF THE CHARTER IN EU LAW}

General principles entail horizontal direct effect. ${ }^{25}$ In Egenberger, the CJEU concluded that the prohibition of discrimination on grounds of religion is a general principle of EU law. In the case at hand, the prohibition in Article 21(1) of the Charter, according to the CJEU, 'is sufficient in itself to confer on individuals a right which they may rely on as such in disputes between them in a field covered by EU law,. ${ }^{26}$ The rules have to be able to confer rights on individuals on its own and this is a condition for it to be able to have horizontal direct effect. ${ }^{27}$ The CJEU reiterated national courts are obliged to disapply any contrary provision of national law in a dispute between two individuals. ${ }^{28}$ The most remarkable aspect of Egenberger was its claim of equating a general principle of EU law and the Charter. The CJEU said the 'prohibition of all discrimination on grounds of religion or belief is mandatory as a general principle of EU law', and ' $[\mathrm{t}$ ] hat prohibition, which is laid down in Article 21(1) of the Charter, is sufficient in itself to confer on individuals a right which they may rely on as such in disputes between them in a field covered by EU law'. ${ }^{29}$ This claim, effectively meant that the provision of the Charter had horizontal direct effect.

The Egenberger judgment did not touch upon Article 51 of the Charter because the matter in question was a general principle of EU law - prohibition of all discrimination grounds of religion or belief. As put, the CJEU 'disregard[ed] the Explanations on the Charter'. ${ }^{30}$ Article 51 of the Charter stands the potential to be circumvented by the finding of general principles of EU law. ${ }^{31}$ The prior judgments of Mangold and Kücükdeveci explain this, both before and after the entering into force of the Charter. The former, Mangold, a general principle was uncovered on foot of a directive, and was found to be a part of the 'constitutional traditions common to the Member States'. ${ }^{32}$ Kücükdeveci cleared up some of

\footnotetext{
25 On the general principles of EU law, see, Katja S Ziegler, Violeta Moreno-Lax and Päivi Johanna Neuvonen (eds), Research Handbook on General Principles of EU Law (Edward Elgar 2021); Takis Tridimas, The General Principles of EU Law (Second Edition, Oxford University Press 2006); Xavier Groussot, General Principles of Community Law (Europa Law Publishing 2006).

${ }^{26}$ Case C-414/16, Vera Egenberger v Evangelisches Werk, für Diakonie und Entwicklung e.V., ECLI:EU:C:2018:257, para 76.

27 ibid, para 78.

28 ibid, para 82.

29 ibid, para 76.

${ }^{30}$ Elise Muir, 'The Horizontal Effects of Charter Rights given Expression to in EU Legislation, from Mangold to Bauer' (2020) 13 Review of European Administrative Law 185.

31 Maciej Szpunar, 'The Authority of EU Law: The Case of Horizontal Application of Fundamental Rights' in Wolfgang Heusel and Jean-Philippe Rageade (eds), The Authority of EU Law: Do We Still Believe in It? (Springer 2019), 129.

32 Case C-144/04, Werner Mangold v Rüdiger Helm, ECLI:EU:C:2005:709, para 74.
} 
Mangold's loose ends, ${ }^{33}$ by more affirmatively bringing Article 21 of the Charter into the equation of the general principle. ${ }^{34}$ Yet it should be noted that Article 51 of the Charter itself does not exclude horizontality. As put by the CJEU itself, Article 51(1) of the Charter 'does not...address the question whether those individuals may, where appropriate, be directly required to comply with certain provisions of the Charter and cannot, accordingly, be interpreted as meaning that it would systematically preclude such a possibility'. ${ }^{35}$

After Egenberger was the Bauer case. The question at hand did not concern discrimination, but nonetheless demonstrated that horizontal direct effect of the Charter covered some aspects, in this case, social rights. The Advocate General in Bauer suggested that the Charter had horizontal direct effect, without the need for a directive to give it specific expression. As put, 'the adoption of an act of secondary EU law and/or implementing measures by the Member States may certainly be useful to allow individuals to benefit in practice from the fundamental right concerned....[but]...[t] hat said, the adoption of such measures, which is not required by the wording of the relevant provision of the Charter, is not necessary in order for that provision directly to produce its effects in disputes which must be resolved by national courts'. ${ }^{36}$ Pre-Bauer, such an approach to the Charter without the content of a directive giving the Charter specific expression had been called 'normatively unclear and methodologically unsound'. ${ }^{37}$ This was potentially one reason why the CJEU did not follow the Advocate General explicitly.

Rather in Bauer, the CJEU insisted that the directive be present in order to establish horizontal direct effect of the Charter. Paid annual leave for heirs in the directive at hand, both in the public and private sector, was found to be a general principle of EU law. The case established a right for workers to receive paid annual leave as an 'essential principle of EU social law', and a corresponding obligation on the employer to grant periods of paid leave. ${ }^{38}$ In one way, Bauer was 'a solid constitutional proclamation of rights'. ${ }^{39}$ The Charter therefore applied as a constitutional guide for courts to strive towards when interpreting national law in the light of the relevant provision of the Charter, adding additional weight to the directives in question.

The last of the three cases demonstrable as a matter of EU law in this article is Cresco Investigation. Here the CJEU confirmed that prohibition on discrimination on grounds of

\footnotetext{
${ }^{33}$ Mangold was not well received in all quarters. Even the most favourable readings from outside of the CJEU criticised lack of rigour in terms of the reasoning offered. See, Takis Tridimas, 'Horizontal Effect of General Principles: Bold Rulings and Fine Distinctions' in Ulf Bernitz, Xavier Groussot and Felix Schulyok (eds), General Principles of EU Law and European Private Law (Kluwer Law International 2013).

${ }^{34}$ Case C-555/07, Seda Kücükedeveci v Swedex GmbH \& Co. KG., ECLI:EU:C:2010:21.

35 Joined Cases C-569/16 and C-570/16, Stadt Wuppertal v Maria Elisabeth Bauer and Volker Willmeroth v Martina Broßonn, ECLI:EU:C:2018:871, para 87.

36 Opinion of Advocate General Bot, Joined Cases C-569/16 and C-570/16, Stadt Wuppertal v Maria Elisabeth Bauer and Volker Willmeroth v Martina Broßonn, ECLI:EU:C:2018:337, para 83.

37 Takis Tridimas, 'Fundamental Rights, General Principles of EU Law, and the Charter' (2014) 16 Cambridge Yearbook of European Legal Studies 361, 368.

38 Joined Cases C-569/16 and C-570/16, Stadt Wuppertal v Maria Elisabeth Bauer and Volker Willmeroth v Martina Broßonn, ECLI:EU:C:2018:871, para 90.

${ }^{39}$ Eleni Frantziou, '(Most of) the Charter of Fundamental Rights Is Horizontally Applicable: ECJ 6 November 2018, Joined Cases C-569/16 and C-570/16, Bauer et Al’ (2019) 15 European Constitutional Law Review 306.
} 
religion was a general principle in EU law. ${ }^{40}$ Specifically, it said that 'until the Member State concerned has amended its legislation...in order to restore equal treatment', ${ }^{41}$ the private actor must comply with the effect of Article 21 of the Charter, as also contained in a directive, for which national courts are 'obliged to guarantee individuals the legal protection afforded to [persons] under Article 21 of the Charter and to guarantee the full effect of that article, ${ }^{42}$ even against private actors. Therefore, the provision of the Charter in question, given specific expression to from a directive, did indeed have horizontal direct effect. By stating this, the CJEU found that the employee shall have the right and payment they were entitled to from the employer, and not compensation from the state. This moved the financial responsibility from the state to the employer.

Whilst these new waves of Grand Chamber judgments of the CJEU were handed down in relation to the Charter, they also were with regard directives that had to be implemented in Member States. Cumulatively therefore, what is evident from this new strand of case law is that directives in themselves are not being given direct effect, but rather, the horizontal direct effect of the Charter, when had been given specific expression to from a directive. This new strand of case law demonstrates that the typical understanding of non-horizontality in EU law is slowly being eroded, even if this new strand of case law is being based upon the Charter. As noted in Egenberger, 'the national court would be required to ensure within its jurisdiction the judicial protection for individuals flowing from...the Charter, and to guarantee the full effectiveness of those articles'. ${ }^{43}$

In all, the CJEU is giving horizontal direct effect to some provisions ${ }^{44}$ of the Charter when given specific expression to from a directive. Despite warnings about the downsides of giving horizontal direct effect to provisions of the Charter, ${ }^{45}$ the CJEU has gone ahead and proceeded to do so. These cases, amongst others that have followed, mark the opening of a new chapter on horizontal direct effect. The way that it has been dealt with by the CJEU does not distort the distinction between the regulations and directives that was of concern back in Marshall I, but the Charter certainly has made the horizontal direct effect of EU law more salient.

The Charter plays into and dictates how directives are interpreted in the EU and this case law on directives is infused with Charter-related references. Many of the directives interpreted by the CJEU in EU law in these cases are also relevant to EEA law. This will make it increasingly harder for the EFTA Court to distinguish the rules deriving from the directives and the rules deriving from the Charter. The main risk in EEA law, therefore, is what is occurring regarding directives that are given specific expression in a Charter

\footnotetext{
40 Case C-193/17, Cresco Investigation GmbH v Markus Achatzi, ECLI:EU:C:2019:43.

41 ibid, para 89.

42 ibid, para 78.

${ }^{43}$ Case C-414/16, Vera Egenberger v Evangelisches Werk für Diakonie und Entwicklung e.V., ECLI:EU:C:2018:257, para 79.

${ }^{44}$ For example, Article 27 of the Charter has shown to not have direct effect, given that a directive did not give it sufficient expression. Case C-176/12, Association de médiation sociale v Union locale des syndicats CGT and Others, ECLI:EU:C:2014:2 ('AMS'), paras 41-51. That said, a future directive could very well result in a change in the CJEU's approach.

${ }^{45}$ See, Dorota Leczykiewicz, 'Horizontal Application of the Charter of Fundamental Rights' (2013) 38

European Law Review 479.
} 
provision. Given the directive stands alone in EEA law without the Charter, this gives rise to unequal protection of fundamental rights in the EFTA pillar of the EEA.

\section{DIRECT EFFECT AND STATE LIABILITY IN EEA LAW}

Other than when the horizontal direct effect of the Charter is found possible through specific expression to from a directive; the other possible remedy for individuals and economic operators when an EU Member State fails in their obligations to correctly implement directives is through the doctrine of state liability. The doctrine allows the possibility for individuals and economic operators to receive compensation for breaches of EU law, which was introduced by the CJEU in Francovich, ${ }^{46}$ along with applicable conditions, which have later been subject of its own nuances and clarifications. Before this, it was solely up to the EU Member State to provide protection and compensation for such violations. With Francovich, this shifted, ensuring that the EU Member State, when certain conditions occur, are liable to compensate losses for individuals and economic operators that have occurred when it, a Member State, has not fulfilled its obligations under EU law.

The increased and broader scope of horizontal direct effect of the Charter, when given specific expression to from a directive, demonstrated in Egenberger, Bauer, and Cresco Investigation has changed and minimised the scope of state liability in EU law, which gives preference to potential horizontal direct effect before state liability. Whilst this enhances the material effectiveness of EU law in EU Member States, this development is not without problems. Whilst related, direct effect and state liability are two different solutions to what is often the same problem. For direct effect, the rule that the EU Member State has failed to implement or has not correctly implemented a directive will be adequately dealt with by CJEU, ensuring the effectiveness of EU law in some way; while for state liability, the rule does not take effect, which the EU Member State instead gets punished for, leaving individuals and economic operators to be able to claim compensation for their lack of correct implementation of the rule. However, whilst direct effect and state liability are solutions to what is often the same problem, they can be disconnected. As the CJEU stated in Brasserie du Pêcheur, fulfilment of the conditions for state liability in EU law is not dependent on the fact that the conditions for direct effect are present. ${ }^{47}$ In some cases, these conditions will coincide, but they cannot be treated as being the same. As put, state liability appears as a safety net, where other devices fail. ${ }^{48}$

An old-age debate in EEA law concerns the potential of both direct applicability and direct effect of EEA law. ${ }^{49}$ Opinion 1/91 expressed the CJEU's fears that direct effect in EEA law, as then merely envisaged, would be absent. Specifically, it said that the EEA Agreement

\footnotetext{
${ }^{46}$ Joined Cases C-6/90 and C-9/90, Andrea Francovich and Danila Bonifaci and others v Italian Republic, ECLI:EU:C:1991:428.

${ }^{47}$ Joined Cases C-46/93 and C-48/93, Brasserie du Pêcheur SAv Bundesrepublik. Deutschland and The Queen v Secretary of State for Transport, exparte: Factortame Ltd and others, ECLI:EU:C:1996:79, paras 19-22.

48 Sacha Prechal, 'Member State Liability and Direct Effect: What's the Difference After All?' (2006) 17

European Business Law Review 299-316, 301.

49 On the differences between direct applicability and direct effect more generally as a matter of EU law, see, J. A. Winter, 'Direct Applicability and Direct Effect: Two Distinct and Different Concepts in Community Law' (1972) 9 Common Market Law Review 425-438.
} 
was 'without recognizing the principles of direct effect', ${ }^{50}$ and that the EFTA states applying the EEA Agreement were to merely revise their national laws to give such law effect. Thirty years later, these fears still hold true, in that EU-style direct effect is not present in EEA law. To date, the EFTA Court's attitude to direct effect has been called 'flexible, ${ }^{51}$ because nothing is ruled affirmatively in or out. However, it is evident from a line of rulings that the EFTA Court interprets the law before it as opportunities to ensure, in some way, that EEA law is given as much effect as possible within the confines of the EEA legal framework.

All the way back as far as Restamark, ${ }^{52}$ the EFTA Court's first case, it was established what has later been referred to as 'quasi-direct effect'. This entails that once a provision has been implemented into the legal orders of the EFTA state, it can be relied upon by individuals and economic operators. ${ }^{53}$ Post-Restamark, the issue on direct effect in the EEA law was once again addressed by the EFTA Court in Sveinbjörnsdóttir and Karlsson. ${ }^{54}$ In the former, the EFTA Court stated that Article 7 EEA and Protocol 35 does not entail 'a transfer of legislative powers' and continued by stating that 'EEA law does not require that individuals and economic operators can rely directly on non-implemented EEA-rules before national courts' ${ }^{55}$ Therefore, the EFTA Court rejected direct effect, for which actors could not rely on non- or incorrectly implemented directives in national courts of EFTA states. Notwithstanding this however, state liability in EEA law was confirmed, and was not contingent upon recognition of a corollary doctrine of direct effect. ${ }^{56}$ The EFTA Court continued noting that according to the objectives of the EEA Agreement, national courts shall consider any relevant element of EEA law, implemented or not, when interpreting national law. ${ }^{57}$

By confirming that EEA law is a 'distinct legal order of its own', ${ }^{58}$ a striking parallel to the CJEU's V an Gend en Loos, the EFTA Court took the EEA Agreement to a new level of understanding. At the same time however, the EFTA Court was a little cautious, and drew a vague outer limit to the effect of EEA law, noting that 'the depth of integration' of the EEA Agreement for EFTA states was less far-reaching than under the EU treaties for EU Member States. ${ }^{59}$ With this, the EFTA Court made it clear that the EEA Agreement had proceeded the limits and intentions set by the EFTA states that entered into the EEA Agreement. This qualification of the state liability doctrine in EEA law would naturally have consequences if

\footnotetext{
50 Opinion 1/91, Opinion of the Court, ECLI:EU:C:1991:490, para 27.

${ }^{51}$ Maria Elvira Méndez Pinedo, EC and EEA Law: A Comparative Study of the Effectiveness of European Law (Europa Law Publishing 2009) 152.

${ }^{52}$ Case E-1/94, Ravintoloitsijain Liiton Kustannus Oy Restamark, Judgment of the EFTA Court of 16 December 1994.

${ }^{53}$ Catherine Barnard, 'Reciprocity, Homogeneity and Loyal Cooperation: Dealing with Recalcitrant National Courts?' in EFTA Court (ed), The EEA and the EFTA Court: Decentred Integration (Hart Publishing 2014) 154.

${ }^{54}$ Case E-9/97, Erla María Sveinbjörnsdóttir v Iceland, Advisory Opinion (Judgment) of the EFTA Court, 10

December 1998, para 63.

${ }_{55}$ Case E-4/01, Karl K. Karlsson bf. $v$ The Icelandic State, Judgment of the EFTA Court of 30 May 2002, para 28.

56 ibid, para 27.

57 ibid, para 28.

${ }^{58}$ Case E-9/97, Erla María Sveinbjörnsdóttir v Iceland, Advisory Opinion (Judgment) of the EFTA Court, 10

December 1998, para 59.

59 ibid.
} 
EU law were begin to develop in other directions. One of these directions is the horizontal direct effect of the Charter, when given specific expression to from a directive.

After Sveinbjörnsdóttir in Karlsson, the EFTA Court clearly stated that direct effect and state liability can be, and are separated in EEA law, given that direct effect of directives is not possible. ${ }^{60}$ Yet going beyond Sveinbjörnsdóttir, it further extended the doctrine of state liability and made it clear that state liability was a vital part of EEA law, covering not just non- or incorrectly implemented directives, but also, in situations more generally when a states has 'breache[d]... its obligation under EEA law' ${ }^{61}$ Later however, the developments in state liability in EEA law have not totally followed the same doctrine in EU law. For example, in HOB-vin, the EFTA Court stated that the development of the doctrine of state liability, whilst integral to EEA law, differed from the case law on the same doctrine from the CJEU, ${ }^{62}$ implying that the application of doctrine might not necessarily be coextensive in all respects. ${ }^{63}$ HOB-vin thereby suggests that the EFTA Court finds that the doctrine of state liability has a more central position and important rule in EEA law than it does in EU law.

\section{HORIZONTAL DIRECT EFFECT OF THE CHARTER: IMPLICATIONS AND OPTIONS FOR EEA LAW}

With the Charter now being further operationalised in the EU and its Member States, there has been a shift in emphasis from adjudication of economic rights to fundamental rights integration, with the Charter a new instrument of choice by individuals seeking to rely upon it. Given the predominance of state liability in EEA law (Section 4), and the newly-found horizontal direct effect of the Charter in certain circumstances, such as when given specific expression to from a directive (Section 3), this gives rise to the pertinent question, and flowing questions therefrom: what would happen if the same events that occurred in Egenberger, Bauer, or Cresco Investigation happened in one of the EFTA states that applies the EEA Agreement? Would there be a clear breaking point between EU law and EEA law where the EFTA state would be held liable, as opposed to in EU where horizontal direct effect of the Charter was applied? Alternatively, would such events result in the extension of the scope of state liability in the EFTA states? Such questions result in a number of considerations for EEA law, given these new developments in EU law. In this section, five options are presented and discussed as a way to demonstrate the strengths and weaknesses regarding the different possibilities for EEA law.

To illustrate why the developments in the EU legal order on horizontal direct effect need to be considered in EEA law can be illustrated using the Bauer case. If the circumstances in those cases would have occurred in an EFTA state applying the EEA Agreement, with that EFTA state not having implemented the rules correctly, it would, according to EEA law

\footnotetext{
${ }^{60}$ Case E-4/01, Karl K. Karlsson hf. $v$ The Icelandic State, Judgment of the EFTA Court of 30 May 2002, paras $25-34$.

61 ibid, para 32.

${ }^{62}$ Case E-2/12, HOB-vín ehf. v Afengis- og tóbaksverslun rikisins, Judgment of the EFTA Court of 11 December 2012, para 120.

${ }^{63}$ Halvard Haukeland Fredriksen, 'The EFTA Court and the Principle of State Liability: Protecting the Jewel in the Crown' in EFTA Court (ed), The EEA and the EFTA Court: Decentred Integration (Hart Publishing 2014) 333-334.
} 
and judicial practice at the EFTA Court, not be resolved through horizontal direct effect of Charter provisions, despite having specific expression given to such from a directive. In such a hypothetical situation in an EFTA state, the go-to remedy would be state liability. This, it is submitted, is a divergent approach in how EU law and EEA law applies different means to rules that ultimately stemmed from the same directive. Therefore, in time, this would lead to even-greater homogeneity divergence, and a problem for the viability of EEA law as a sufficient solution to EFTA states latching onto the internal market, without the EFTA states being EU Member States. If EEA law is not meant to cover and protect individuals and economic operators in the same way as EU law does on an equivalent matter, then, at very least, this should be addressed in some way. There is no shortage of options.

\subsection{OPTION 1 FOR EEA LAW - NARROWER CONCEPTION OF STATE LIABILITY}

The first option in EEA law would be for the EFTA Court to follow state liability in the same way as the CJEU does, but not include cases covered by direct effect at the CJEU. This would be a very narrow interpretation of the doctrine of state liability. This would, in essence, be the same as the conditions for state liability in EU law that began to be developed from Francovich. But where the rule on state liability is 'the safety net when other mechanisms fails' in the $\mathrm{EU},{ }^{64}$ it is the only available remedy for individuals in the EFTA states. The upside to this option this would be the fact that state liability is interpreted uniformly throughout both the EU and the EEA. This would ensure the same application and interpretation of the doctrine, which will mean that there is no need to differentiate between the two legal orders.

However, giving effect to the same exact rule and scope of the rule, does not, in this instance, mean that the same result is achieved. By having the same rules on the doctrine of state liability, legal homogeneity is actually not created, as the EU has additional tools to cover breaches beyond state liability, which the EEA does not. Without direct effect in the EEA, the coextensive application of the rules surrounding the doctrine of state liability rules will leave open a gap, offering less protection in the EEA than in the EU, which again is not in line with the principle of homogeneity that underpins EEA law. ${ }^{65}$ As analysed above, state liability in the EEA is not dependent on the application of state liability in EU law. This option would mean that there is less protection for individuals in EEA law, and that the EFTA states could neglect the rights of individuals and economic operators.

Adapting this narrow point of view of the doctrine of state liability in EEA law, without including the other mechanism of direct effect, would be a huge loss for individuals

\footnotetext{
${ }^{64}$ Sacha Prechal, 'Member State Liability and Direct Effect: What's the Difference After All?' (2006) 17 European Business Law Review 299, 309.

${ }^{65} \mathrm{On}$ another divergence between the two legal orders is what constitutes a referring body for the purposes of the preliminary reference procedure under Article 267 TFEU by the CJEU, versus the a referring body for the purposes of the advisory opinion procedure under Article 34 SCA by the EFTA Court. See, Graham Butler, 'Mind the (homogeneity) gap: Independence of referring bodies requesting advisory opinions from the EFTA Court' (2020) 44 Fordham International Law Journal. This is all the more serious in light of the Banco de Santander judgment of the CJEU, delivered in Grand Chamber in January 2020. See, Case C-274/14, Proceedings brought by Banco de Santander SA, ECLI:EU:C:2020:17. Graham Butler, 'Independence of Non-Judicial Bodies and Orders for a Preliminary Reference to the Court of Justice' (2020) 45 European Law Review 870.
} 
and economic operators. This solution would ultimately set the legal development of the EEA back in time. In the current legal climate, where individuals are typically offered a higher degree of protection in EU law, this option in EEA law is unwise, and unlikely to be a real solution.

\subsection{OPTION 2 FOR EEA LAW - WIDER CONCEPTION OF STATE LIABILITY IN EEA LAW}

The second option for EEA law would be for the EFTA Court to extend the applicability of state liability to cover the situations solved in the EU legal order through the horizontal direct effect of the Charter, when given specific expression to from a directive. This would not necessarily mean that it would be an extension of the state liability as a whole, but that the scope of the doctrine of state liability would remain similar to the manner in which it is currently applied. By opting for this approach, the EFTA Court would move in the opposite direction to the CJEU case law and the effects of its new horizontal direct effect jurisprudence, which results in situations where there will be fewer cases at the CJEU solved through the doctrine of state liability.

This option would be in compliance with the assumed position of EFTA states applying the EEA Agreement, whom may wish to continue to be held accountable under state liability, rather than to have horizontal direct effect be possible for individuals and economic operators. By adopting a wider conception of state liability, this would form a clear distinction between EU law and EEA law, especially given that when it comes to that the obligation to transpose relevant directives into national law, the obligation falls solely on the state, leaving a higher expectation on EFTA states applying the EEA Agreement to perform implementation duties than there is for EU Member States.

A wider conception of the doctrine of state liability may form in such a way that all breaches are covered, marking an objective interpretation where each and every breach by the state is sufficiently serious to constitute a breach. This would mean that the EFTA Court would have to further distance itself from the interpretation of the doctrine by the CJEU, something that the EFTA Court began doing in HOB-vin, ${ }^{66}$ to that extent and this makes it clear that the terms of state liability can exist side-by-side, but that the condition for establishing a breach is sufficiently serious is different. ${ }^{67}$

This option would furthermore imply that the remedies for breaches according to the EEA Agreement would, de facto, be stricter and harsher on the EFTA state than a similar breach for an EU Member State. However, this would at least offer a higher degree of protection for individuals and economic operators, and would keep in line with the proposition that the state is responsible for fulfilling its obligations, and that this obligation should not be transferred to individuals and economic operators. This solution would be consistent with the views of the Advocate General in Cresco Investigation, ${ }^{68}$ where the point was raised that employers should not bear the cost of a state's failure to comply with its

\footnotetext{
${ }^{66}$ Case E-2/12, HOB-vín ehf. v Afengis- og tóbaksverslun rikisins, Judgment of the EFTA Court of 11 December 2012.

67 ibid, para 120.

68 Opinion of Advocate General Bobek, Case C-193/17, Cresco Investigation GmbH v Markus Achatzi,

ECLI:EU:C:2018:614, para 183.
} 
obligations, since the employers are just following national law. Shifting the cost over to the individuals that are just following the national law is a problematic side to horizontal direct effect, and makes it less likely for the state to have to bear the cost of their failure to comply with EU rules.

Two further issues arise if this option is to be seriously considered as an adopted approach in EEA law. First is the consideration of whether EFTA states applying the EEA Agreement should be more exposed and cover more situations in EEA law than EU Member States in a comparative situation in EU law. Secondly, this option would also, in practice, give anyone but the state the opportunity to take advantage of the failure to imply the directives correctly, which could then create an opportunistic and unwanted side effect.

If the EFTA Court decides to widen the scope of state liability in EEA law, distinguishing it from state liability in the EU, the question would then be what the best way of doing this would be. The obvious and most likely option would probably be to build on and extend the findings of the EFTA Court in HOB-vin, ${ }^{69}$ lowering the degree of seriousness of the breach to be either all breaches; or alternatively, alter the way of interpreting what it means for a breach to be 'sufficiently serious'. ${ }^{70}$ If this option would be adopted in EEA law, the approach ought to be that all breaches are 'sufficiently serious', but having an exception for abusive behaviour. This option would therefore, in essence, create strict liability for the EFTA state in given situations.

\subsection{OPTION 3 FOR EEA LAW - HORIZONTAL DIRECT EFFECT OF THE CHARTER}

The third option for EEA law would be for the EFTA Court to introduce horizontal direct effect of the Charter in EEA law, when a provision of the Charter in question has been given specific expression to from a directive. This would be applying the legal sources in the same way as the CJEU does with respect to the Charter provisions. In essence, this would be adopting an effects-based approach to EEA law, and ensuring homogeneity between EU law and EEA law. As argued, state liability, in itself, can 'never be a substitute for...the application of...direct effect'. ${ }^{71}$ Rather, it can be seen as a complementary doctrine. Therefore, for the doctrine of direct effect to make it into EEA law, it would first need to be established by making regulations directly applicable, which is in line with the CJEU's view of EEA law. ${ }^{72}$

\footnotetext{
${ }^{69}$ Case E-2/12, HOB-vín ehf. v Afengis- og tóbaksverslun rikisins, Judgment of the EFTA Court of 11 December 2012.

${ }^{70}$ Joined Cases C-6/90 and C-9/90, Andrea Francovich and Danila Bonifaci and others v Italian Republic, ECLI:EU:C:1991:428, para 40. For an overview of the conditions for liability, and the subsequent clarification of Francovich in EU law, see, Robert Schütze, European Union Law (Second edition, Cambridge University Press 2018) 421-427.

${ }^{71}$ Leif Sevón, 'The ECJ, the EFTA Court and the national courts of the EFTA countries' in Peter Lødrup and others (eds), Rettsteori og rettsliv: Festskrift til Carsten Smith (Universitetsforlaget 2002) 730.

72 Case C-431/11, United Kingdom of Great Britain and Northern Ireland v Council of the European Union, ECLI:EU:C:2013:589, paras 53-54; and, Case C-83/13, Fonnship A/S v Svenska Transportarbetareförbundet and Facket för Service och Kommunikation (SEKO) and Svenska, ECLI:EU:C:2014:2053, para 24. On this, see, Tarjei Bekkedal, 'Understanding the Nature of the EEA Agreement: On the Direct Applicability of Regulations' (2020) 57 Common Market Law Review 773.
} 
EEA law itself does not have a prescriptive catalogue of fundamental rights in the same way that EU law does. But that is not to say that fundamental rights are absent from EEA law altogether. The EFTA Court incorporates fundamental rights under the European Convention on Human Rights (ECHR) into its case law, ${ }^{73}$ and has said the provisions of the ECHR and the judgments of the European Court of Human Rights (ECtHR) are important sources for determining the scope of... rights' ${ }^{74}$ This has been further extended in Holship to confirm that ' $[\mathrm{f}]$ undamental rights form part of the unwritten principles of EEA law', ${ }^{75}$ and that such rights 'guaranteed in the EE $A$ legal order are applicable in all situations governed by EEA law'. ${ }^{76}$ The EFTA Court, however, was not explicit about which rights are guaranteed, and did not rule out such guaranteed rights in EEA law being the Charter itself. That said, it has been argued that with fundamental rights being unwritten principles of EEA law, this would extend only to the ECHR, as EFTA states applying the EEA Agreement are contracting parties to that, ${ }^{77}$ and not, per se, the Charter.

The EFTA Court has not, thus far, been keen on using the Charter in its adjudication more generally. The Charter is not a part of EEA law, and does not have formal legal status, but it would not be correct to say it has no legal value in EEA law. There is a way in which the effects of the Charter could come into EEA law, without the Charter necessarily being part of EEA law. Directives that are a 'Text with EEA Relevance' are interpreted by the EFTA Court, with some of these directives having preambles which may reference to the Charter. Consequently, in the EFTA Court's adjudication, it would be strange if the EFTA Court did not at least look to the Charter to assist it in the adjudication process. ${ }^{78}$ As forcefully put, it would be 'unclear how the EFTA Court could simply ignore such recitals'. ${ }^{79}$ And whilst it may be perceived, at least in some quarters, as 'a not so straightforward substantial judge made amendment to the EEA Agreement', ${ }^{80}$ it is nonetheless accepted that it is 'awkward' if the EFTA Court acts 'as if the Charter did not exist, completely ignoring its provisions and the [CJEU]'s case law related to it'. ${ }^{81}$ Furthermore, it can be argued that it might even be

\footnotetext{
${ }^{73}$ For example, Case E-8/97, TV 1000 Sverige AB v The Norwegian Government represented by the Royal Ministry of Cultural Affairs, Advisory Opinion (Judgment) of the EFTA Court of 12 June 1998, para 26. Generally, Robert Spanó, 'The EFTA Court and Fundamental Rights' (2017) 13 European Constitutional Law Review 475.

${ }^{74}$ Case E-2/03, Akerwvaldid (The Public Prosecutor) v Asgeir Logi Ásgeirsson, Axel Pétur Ásgeirsson and Helgi Már Reynisson, Judgment of the EFTA Court of 12 December 2003, para 23.

${ }^{75}$ Case E-14/15, Holship Norge AS v Norsk Transportarbeiderforbund, Judgment of the EFTA Court of 19 April 2016, para 123.

76 ibid, emphasis added.

${ }^{77}$ David Thór Björgvinsson, 'The EEA Agreement and Fundamental Rights' in Lucius Caflisch and others (eds), Liber Amicorum Lu₹ius Wildhaber: Human Rights - Strasbourg Views, Droits de l'homme - Regards de Strasbourg (NP Engel Verlag 2007) 40.

${ }^{78}$ Beyond directives, there is also the issue of regulations. For example, the General Data Protection Regulation (GDPR) (2016/679) in the preamble relies on the Charter. Interpretation of the GDPR is currently before the EFTA Court. Joined Cases E-11/19 and E-12/19 Adpublisher AG v J \& K, pending. ${ }^{79}$ Nils Wahl, 'Unchartered Waters: Reflection on the Legal Significance of the Charter under EEA Law and Judicial Cross-Fertilisation in the Field of Fundamental Rights' in EFTA Court (ed), The EE $A$ and the EFTA Court: Decentred Integration (Hart Publishing 2014) 288.

80 Arnfinn Bårdsen, 'Fundamental Rights in EEA Law - The Perspective of a National Supreme Court Justice' (Spring Seminar, EFTA Court, Luxembourg, 12 June 2015)., para 21.

$81 \mathrm{ibid}$, para 22.
} 
warranted that the EFTA Court rely explicitly in its adjudication on the Charter, facilitating a more honest approach to its reasoning. The case of DB Schenker can shed some light on how the Charter might function in EEA law. Here, the EFTA Court said that the principle of homogeneity 'cannot be restricted to the interpretation of provisions whose wording is identical in substance to parallel provisions of EU law'. ${ }^{82}$ Consequently, therefore, this can serve as an established premise for the EFTA Court to use the Charter, despite the Charter not being a core component of EEA law.

The EFTA Court has acknowledged the potential effect of the Charter in both Posten Norge ${ }^{83}$ and Clauder, ${ }^{84}$ but the ECHR still appears to be the baseline, as evidenced in Jabbi ${ }^{85}$ In Clauder, passing reference was made to seeing the ECHR and the Charter as corresponding. Here, the EFTA Court stated that a provision of the ECHR was 'the same right' protected in the Charter. ${ }^{86}$ This, whilst admirable in attempting to ensure fundamental rights protection in the EEA, ${ }^{87}$ does not fully resolve the issues. Whilst seeing rights correspondence between the ECHR and the Charter, the EFTA Court has thus far not addressed rights correspondence between a directive and the Charter. That said, the Clauder judgment does leave it open to the EFTA Court in the future to expand on this iteration, should it choose to do so. Around the same time in ESAv Iceland, the Charter coming into EEA law could have occurred. However, the EFTA Surveillance Authority (ESA) and the Norwegian Government pleaded that it was not relevant to the case. ${ }^{88}$ By contrast, Iceland did see that it was to be a matter of relevance. ${ }^{89}$ Notwithstanding the disagreement between the parties on the relevant of the Charter, it was not dealt with in the EFTA Court's judgment..$^{90}$

More interesting is the EFTA Court's utterances in Deveci, where the parties differed on whether the Charter could be invoked or not. As a get-around, the EFTA Court avoided the issue. It stated that in the case, it 'finds no reason to address the question... of the Charter', ${ }^{91}$ and that the provision of the Charter in question 'must be recognised in accordance with EEA law and national law and practices'..$^{92}$ This position does not rule out the horizontal direct effect of the Charter when given specific expression to from a directive in the future, despite the EFTA Court not taking up this opportunity in this instance. Therefore, if a provision in the Charter offers the same level of protection as it is offered in

\footnotetext{
${ }^{82}$ Case E-14/11, DB Schenker v EFTA Surveillance Authority, Judgment of the EFTA Court of 21 December 2012, para 78 .

${ }^{83}$ Case E-15/10, Posten Norge AS v EFTA Surveillance Authority, Judgment of the EFTA Court of 18 April 2012.

${ }^{84}$ Case E-4/11, Arnulf Clauder, Judgment of the EFTA Court of 26 July 2011.

${ }^{85}$ Case E-28/15, Yankuba Jabbi v The Norwegian Government, represented by the Immigration Appeals Board, Judgment of the EFTA Court of 26 July 2016, para 81.

${ }^{86}$ Case E-4/11, Arnulf Clauder, Judgment of the EFTA Court of 26 July 2011, para 49.

${ }^{87}$ Similar efforts by the EFTA Court are seen in Case E-15/10, Posten Norge AS v EFTA Surveillance Authority, Judgment of the EFTA Court of 18 April 2012, paras 84-86.

${ }_{88}$ Case E-12/10, ES A v Iceland, Report for the Hearing, paras 89 and 163.

89 ibid, paras 92 and 125.

${ }^{0}$ Case E-12/10, ESA v Iceland, Judgment of the EFTA Court of 28 June 2011.

${ }^{91}$ Case E-10/14, Enes Deveci and Others v Scandinavian Airlines System Denmark-Norway-Sweden, Judgment of the EFTA Court of 18 December 2014, par 64.

92 ibid.
} 
the ECHR, using the Charter to understand the ECHR, is 'unproblematic'. ${ }^{93}$ However, where levels of protection differ between the Charter and the ECHR come about is where problems arise. The ECHR in some instances covers the same matters as the Charter, but usually, the Charter offers a higher level of protection for individuals and economic operators when it is in play. The EFTA Court can, and may, invoke the Charter in cases before it.

\subsection{OPTION 4 FOR EEA LAW - DO NOTHING}

The fourth option separates itself from the first three, because it does not require any actions from the EFTA Court. On the contrary, it means it does nothing at all. If the EFTA Court chooses not to address the difference in the application of state liability in the EU law and EEA law following the introduction of horizontal direct effect of the Charter when given specific expression to from a directive, and just watch as the gap between EEA law and EU law grow larger, this could lead to a point where it is impossible to tell what the rules for individuals and economic operators are. This might, unfortunately, be the most likely solution in the short term.

The full scope of horizontal direct effect of the Charter, when given specific expression to from a directive, has not yet been made clear by the CJEU, with the cases thus far only covering few provisions of the Charter. The CJEU has been reluctant in making clear statements that applies outside of the specific articles that arose in the cases to date, in light with its policy of judicial minimalism. With a new and undecided area, it might be wise of the EFTA Court to wait until there is a higher degree of clarity on the area from the CJEU, which will come over time, in what is a fluid area of case law. This might be the preferred solution, as the situation currently implies that it does not create any problems either for the states, individuals, and economic operators; but by looking at the possible negative outcomes of not acting, it can also be stated that this should not be a long-term or permanent solution.

Doing nothing would ensure that the EEA legal order is an inferior constitutional arrangement, and thus no longer filling the premise which supports the existence of the EEA Agreement, which is the homogeneity of EEA law with EU law. In time, this would lead to the EEA framework becoming an untenable platform for integration of the EFTA states into the internal market. To not do anything leaves EEA law in a place it does not want to be, because it does not provide clear answers that individuals and economic operators need to make sure that their rights are protected within the internal market. With the complicated relationship between EU law and EEA law being what it is, it needs to be made clear where the line between them goes, and without a clear answer from the EFTA Court, there is no way of knowing what the applicable law would be.

\subsection{OPTION 5 FOR EEA LAW - NATIONAL APPROACHES TO FUNDAMENTAL RIGHTS}

The final option would be seeing national approaches to horizontal direct effect of the Charter, when given specific expression to from a directive, which can be distinguished from the other options in the way that it is not an effort undertaken by the EFTA Court. Rather,

93 Wahl (n 79) 294. 
it would be made by EFTA states applying the EEA Agreement themselves, without the involvement of the EFTA institutions. To some extent, this option is already occurring in Norway. This option works as a workaround for the states when it comes to discrimination. Norway is using the provisions of the Charter and the judgments of the CJEU to form and interpret national law to be in compliance with the EU rules on discrimination. This gives individuals and economic operators the assurance that national law is, at the very least, on par with those in EU law. This is, interestingly, a way that national courts in EFTA states would be avoiding EEA law.

This option might also be beneficial for Norway, as the EFTA state has sufficient room if and when a problem will occur. For example, for an instance where the Norwegian courts disagree with the CJEU, the apparent question is whether the national court is going to follow the CJEU's ruling, regardless of disagreements; or alternatively, if the national court would create its own interpretation, and applying the law as it would see fit. The EFTA states are not limited to just follow rules arising from the EEA Agreement, from it does not restrict states from applying other rules, so long as such rules do not 'jeopardi[s]e the attainment of the objectives of the agreement'. ${ }^{94}$ Accordingly, the Norwegian rules on discrimination are tailored to cover all areas of discrimination covered by the Charter in EU law. Such national laws on discrimination are designed to implement the Charter, even without being a party to the Charter, making clear that Norwegian law is more suitable to solve problems on discrimination than the unclear and unsettled EEA law. Taking this approach, Norway is having it both ways, as it is able to apply law in a way that cannot be pursued by the ESA, or challenged at the EFTA Court.

In this approach, where the EFTA states applying the EEA Agreement are not formally bound by the Charter, this national approach can, in some ways, be seen as the optimal way an EFTA state to ensure uniformity with EU law. This raises questions regarding the loyalty of such an EFTA state, given that it is partially acting outside of the EEA Agreement. When one of three EFTA states applying the EEA Agreement chooses to go outside the EEA system to solve a rather large and complex problem, the two remaining states are left with the two options of either following in the same footsteps; or alternatively, not doing anything, and having no way of assuring that national law is followed, thus leaving their individuals and economic operators at risk. Moreover, there is no certainty that the national laws that are adopted are fully covering the Charter, and this kind of approach makes the homogeneity gap wider, and much more unpredictable.

The legal certainty and possibility of individuals and economic operators of having a case tried at a court beyond the state, such as the EFTA Court, is one of the main arguments for why a national approach is suboptimal. When dealing with EU law, following the interpretations of the CJEU, it is certainly problematic that individuals and economic operators in EFTA states applying the EEA Agreement cannot have their cases heard by the EFTA Court that decides on the matter as a matter of EEA law; compared to individuals and economic operators in a comparative position in EU law at the CJEU. Having a case solved by a national court of an EFTA state interpreting EU law and the jurisprudence of the CJEU, without consequential ramifications for incorrect interpretation, is an unwise

${ }^{94}$ Article 3, second paragraph, EEA Agreement. 
approach. Without a supervisory authority such as the ESA, and an independent judicial body, the EFTA Court, this approach is incisively deficient.

\section{CONTEMPLATING THE WAY AHEAD FOR THE EUROPEAN ECONOMIC AREA}

The Charter is no mere symbolic document, for it is a rights-conferring instrument that, as several judgments of the CJEU have now made clear, can now be invoked horizontally in a given set of legal conditions. Without the Charter, the EFTA states applying the EEA Agreement are lacking an important source of law to establish horizontal direct effect of the Charter when given specific expression to from a directive, as there can be in EU Member States. In those EFTA states, the ECHR does not have the same kind of significance as EU law, and nor does the ECHR possess the same constitutional character as the Charter. EEA law therefore needs to undergo some sort of reform if wants to survive and keep connection to EU law, with the most important aspect being the continued access of EFTA states applying the EEA Agreement to the internal market of the EU. The new direction of CJEU case law on horizontal direct effect of the Charter, when given specific expression to from a directive, opens up a new constitutional conundrum for EEA law. Consequently, the EEA legal order is soon reaching its day of reckoning. The EFTA states applying the EEA Agreement do not wish to be part of the EU legal order, but yet, want access to the internal market of the EU. As put, this dual dynamic demonstrates that EFTA states having been trying to 'have their cake and eat it.' ${ }^{95}$

The Charter has, to date, not become a major part of EEA law. Accordingly, the EFTA Court, as acknowledged by an insider, 'has been cautious as regards the relevance of the Charter. ${ }^{96}$ This was initially a wise position, given that there was some initial uncertainty as to the potential scope of horizontal direct effect arising from the Charter in EU law. Horizontality of the Charter in EU law was previously contemplated, ${ }^{97}$ and despite the wavering in $A M S$ case, the CJEU did not exclude it, but subsequent case law like Egenberger, Bauer, and Cresco Investigation have now all pointed to horizontal direct effect of the Charter when given specific expression to from a directive. The slowly evolving problem is that the norm was typically that there was no horizontal direct effect of directives, which continues to be the case. However, now, if a provision of a directive is replicated in the Charter, that Charter provision may, as a last resort in EU law, be invoked horizontally, if a directive has given specific expression to it.

Critics stand to criticise many of the options that have been put forth above. According to one view, 'highly sophisticated legal acrobatics...[would be needed]...to arrive at...[a]...conclusion that the protection of fundamental rights within the EEA...[that]...is equivalent to...the ECHR'. ${ }^{98}$ This statement alone, albeit about the Bosphorus presumption

\footnotetext{
${ }^{95}$ Skúli Magnússon, 'Efficient Judicial Protection of EEA Rights in the EFTA Pillar - Different Role for the National Judge?' in EFTA Court (ed), The EEA and the EFTA Court: Decentred Integration (Hart Publishing 2014) 130 .

${ }^{96}$ Carl Baudenbacher, Judicial Independence: Memoirs of a European Judge (Springer 2019) 154.

${ }_{97}$ Tridimas, 'Fundamental Rights, General Principles of EU Law, and the Charter' (n 37) 392.

98 David Thór Björgvinsson, 'On the Interplay between EC Law, EEA Law and the European Convention on Human Rights' in Martin Johansson, Nils Wahl and Ulf Bernitz (eds), Liber Amicorum in Honour of Sven
} 
of convention compliance of the EU with the ECHR, as applied to the EEA, is just one demonstrable view of how difficult these matters are from a legal perspective, even without the Charter in the picture. But the evolving case law of the CJEU on the Charter, which is now squarely within the frame, matters are even more complex for EEA law.

It should also be stated that the options offered in this article are by no means exhausted, for there are other varied versions of each of these put forward that could also act as solutions. Yet the continued homogeneity of developments across EU law and EEA law is clearly at issue. As put, 'if the two courts [the CJEU and the EFTA Court] give different interpretations to a provision of [EU] law...that is identical in substance, [then the principle of] homogeneity would clearly be at stake. ${ }^{99}$ The preamble to the EEA Agreement envisages a 'dynamic and homogeneous' area. Given that if the questions asked in Egenberger, Bauer, and Cresco Investigation had come before the EFTA Court first, and not the CJEU as it did, it is likely, given the EFTA Court's jurisprudence thus far, that it would have reached a different conclusion than what the CJEU did.

On this basis, as argued above, it is clear that sometbing has to be done in EEA law to correct this problem. It has been claimed that despite the fact there is no direct effect in EEA law, there are still remedies available given that state liability achieves 'essentially the same results'. ${ }^{100}$ This, whilst may have been a correct claim for the time, is no longer the case. The results, in light of the new CJEU case law, are no longer the same. State liability in no way makes up for having the ability to rely upon direct effect, and the way horizontal direct effect of the Charter is now possible when given specific expression to from a directive. Therefore, the question in EEA law is what to do, and not if something should be done.

The solution that should be avoided at all cost is the first option (narrower conception of state liability). This is because this would create a gap between EU law and EEA law, offering individuals and economic operators in EFTA states applying the EEA Agreement a lot less protection, creating a position that cannot be sustained. State liability, and the possibility for it to be found, is still a live issue in EU law. Some Member States national laws make it incredibly difficult for state liability to be established in national legal orders. The Commission has recently proceeded with infringement proceedings case against a Member State to the CJEU for failing to provide sufficient access to such a remedy, ${ }^{101}$ implying that the doctrine of state liability in EU law is still salient and developing, notwithstanding the potential of horizontal direct effect of the Charter when given specific expression to from a directive. Furthermore, as already indicated, the fourth (do nothing) and fifth options (national approaches to fundamental rights) are unhelpful for securing homogeneity of EU

Norberg: A European for All Seasons (Bruylant 2006) 98. This comment was made as regards the Bosphorus presumption of convention compliance of the EU with the ECHR as not applying to the compliance of the EEA with the ECHR. This view was confirmed in the Konkurrenten.no decison by the ECtHR. Konkurrenten.no AS v Norway (Application no. 47341/15), EctHR, Second Section, 28 November 2019. For criticism of Konkurrenten.no, see, Halvard Haukeland Fredriksen and Stian Øby Johansen, 'The EEA Agreement as a Jackin-the-Box in the Relationship between the CJEU and the ECtHR?' [2020] European Papers.

${ }^{99}$ Sevón (n 71) 728.

${ }^{100}$ Carl Baudenbacher, 'If Not EEA State Liability, Then What? Reflections Ten Years after the EFTA

Court's Sveinbjörnsdóttir Ruling' (2009) 10 Chicago Journal of International Law 333, 368.

101 Case C-278/20, Commission v Spain, pending. 
law and EEA law, and would be detrimental to rights for individuals and economic operators in EFTA states applying the EEA Agreement.

This leaves just two options, which are the two best alternatives for EEA law, and are in the hands of the EFTA Court. These are to either the second option (wider conception of state liability in EEA law), or the third option (horizontal direct effect of the Charter). Introducing direct effect as a whole, starting with regulations, could be a solution, but the most likely outcome will be to extend the scope of state liability, the second option. This would not offer similar solutions to similar problems, but it would be in line with the sui generis view of EEA law offered by the EFTA Court in Sveinbjörnsdóttir, and would provide individuals and economic operators with some protection, although placing a higher burden on the EFTA state applying the EEA Agreement, given that it would become liable in more instances than an EU Member State would in comparable circumstances. Alternatively, if the EFTA Court were to go down the route of introducing direct effect of the Charter in the EEA, when giving specific expression to from a directive, adopting the third option, then this would be a dramatic and drastic change of how the EEA Agreement is interpreted and understood. This would probably not go down well with the EFTA states, but something they could learn to live with, ensuring the effects-based approach of EEA law which is indispensable to ensure the principle of homogeneity. Whilst initially a big move for EEA law, and would naturally be protested against in subsequent cases before the EFTA Court, in time, it would be accepted, just as it took time for the EFTA states to fully acknowledge the doctrine of state liability in the EEA legal order.

From an entirely legal point of view, the introduction of horizontal direct effect of the Charter in EEA law, when given specific expression to from a directive, would be the best solution, in line with the third option, as analysed above. ${ }^{102}$ EEA law is based on its continuing evolution with EU law, which the principle of homogeneity demands. The least that individuals and economic operators deserve is legal certainty. Therefore, it is incumbent that the Charter is given effect to in EEA law in an akin manner to how it may in EU law, when provisions of the Charter are given specific expression to from a directive. This argument is based on clarity, homogeneity, legal certainty, and ensuring concurrent legal developments of EEA law. The introduction of the mere possibility of horizontal direct effect of the Charter, when given specific expression to from a directive, would initially introduce a provisional period where the full scope of the EEA Agreement would be muddied, given it would be revolutionary for the EEA legal order. Yet in the longer term, it would be the correct outcome, as it unites EU law and EEA law in effects-based harmony, and in line with the need to secure the principle of homogeneity.

The only other reasonable option which could offer a good solution for the EEA is more conventional, and that is to extend the application of state liability in the EEA, the second option, to also apply to some of the instances that today is covered direct effect in the EU. This would be to make sure that there is no legal vacuum. It would in turn make the doctrine of state liability, which is the narrow exception in EU law, ${ }^{103}$ the main form of remedy in EEA law. What the EFTA Court called a possible solution in HOB-vin might also be the best way to move forward more generally. An extension of the EFTA Court's findings

102 See Section 5.3 (Option 3 for EEA law - Horizontal direct effect of the Charter) of this article. 103 Prechal, 'Member State Liability and Direct Effect: What's the Difference After All?' (n 64) 309. 
in Sveinbjörnsdóttir and HOB-vin, or in other words, an extension of the scope and applicability of the doctrine of state liability, would be the solution most aligned with the established perspectives of EEA law. However, it is far from the optimal solution, which is, as already stated, and from a strictly legal perspective, the third option.

\section{CONCLUSION}

Rights under the Charter are increasingly becoming more ingrained in wider EU legal thinking, feeding its way into workings within EU Member States. Direct effect too is a right of its own - a form of 'procedural' right to invoke EU law in national settings. ${ }^{104}$ It would be a shame if this newly developed corpus of law on horizontal direct effect in EU law were to be deliberately omitted from the EFTA states that apply the EEA Agreement. The only viable solutions involve action of the EFTA Court. The responsibility lays with it for the future development of the constitutional character of EEA law. The EFTA Court's approach to date has been subtle, and non-committal. In time, it will have to take a more affirmative position. Elsewhere, to paraphrase the words of the one former President of the EFTA Court when discussing the significance of Sveinbjörnsdóttir, ${ }^{105}$ how the EFTA Court chooses to deal with this situation regarding horizontal direct effect could make or break EEA law. It has been argued that the EFTA Surveillance Authority (ESA) must take a more assertive role for compliance issues arising in EFTA states, given the current absence of direct effect. ${ }^{106}$ Certainly this is true, so the question therefore is what kind of assertion the ESA will push for, be it pleading for the EFTA Court to rely on the Charter in its interpretative role, ${ }^{107}$ or alternatively, to press for interpretation that does not do so, and relies on EEA law alone.

There have been corners of academic debate for some time whom have advocated for horizontal direct effect of directives in EU law. ${ }^{108}$ This has not yet come to pass, but the Charter has now come onto the scene, and has seen the potential for the horizontal direct effect of that, when given specific expression to from a directive. Thus, it is worth recalling the Opinion of the Advocate General in Kücükdeveci, whom neatly summed up the stakes before the Charter entered into binding legal force. He stated that:

'[G]iven the ever increasing intervention of [EU] law in relations between private persons, the Court will, in my view, be inevitably confronted with other situations which raise the question of the right to rely, in proceedings between private persons, on directives which contribute to ensuring observance of fundamental rights...[This is because in the C]harter are a number which are already part of the existing body of [EU] law in the form of directives. In that perspective, the Court must, in my

\footnotetext{
104 Sacha Prechal, Directives in European Community Law: A Study of Directives and Their Enforcement in National Courts (Clarendon Press 1995) 125.

105 Baudenbacher (n 96) 129-137.

106 Niels Fenger, Michael Sánchez Rydelski and Titus Van Stiphout, European Free Trade Association (EFTA) and European Economic Area (EEA) (Kluwer Law International 2012) 136.

107 The Report for the Hearing in Joined Cases E-11/19 and E-12/19 Adpublisher AGvJ \& K, pending, a number of parties invoke the Charter in their submissions, including Austria, Ireland, the ESA, and the Commission.

108 For example with respect to directive in themselves, which has still not come about, see, Takis Tridimas, 'Horizontal Effect of Directives: A Missed Opportunity' (1994) 19 European Law Review 621.
} 
view, think now about whether the designation of rights guaranteed by directives as fundamental rights does or does not strengthen the right to rely on them in proceedings between private parties ${ }^{109}$

By analogy, EEA law is facing a similar conundrum that is going to have to be answered at a near juncture. The doctrine of state liability in EEA law, beginning with Sveinbjörnsdóttir, cannot alone continue to be central to the functioning and application of EEA law and its system of limited remedies.

How the EFTA Court chooses to deal with horizontal direct effect and the place of the Charter in EEA law may be decisive for the future of EEA law as we know it. Horizontal direct effect would, it is submitted by a former Advocate General, 'offer an appropriate way of making the judicial protection which individuals deserve complete, coherent[,] and equal for all'. ${ }^{110} \mathrm{He}$ also stated that such a doctrine should exist in EEA law on the basis of Article 6 of the EEA Agreement. ${ }^{111}$ This was a view on directives that the CJEU has not yet taken, but given the place of the Charter in the current era, anything in possible in the future.

As another former President of the EFTA Court and later a judge of the CJEU has stated, 'ensuring the survival of the EEA, as we know it today,... [means that] the principle] of direct effect' must apply, even if that means direct effect in a different form that than in EU law. ${ }^{112}$ This latter approach is correct, and demonstrates an open, problem-solving attitude to arising issues in EEA law, which, regrettably, is a minority in scholarship on EEA law. Taking this open-minded approach means that relevant actors and interests in the EEA can begin to have serious discussion about the future of EEA law in light of the arising developments in EU law. Horizontal direct effect in both EU law and EEA law has much runway ahead of itself.

\footnotetext{
109 Opinion of Advocate General Bot, Case C-555/07, Seda Kücükdeveci v Swedex GmbH \& Co. KG., ECLI:EU:C:2009:429, para 90.

110 Walter Van Gerven, 'The Horizontal Effect of Directive Provisions Revisited: The Reality of Catchwords' in Deirdre Curtin and Tom Heukels (eds), Institutional Dynamics of European Integration: Essays in Honour of Henry G. Schermers, Volume II (Martinus Nijhoff Publishers 1994) 348.

111 See, Walter Van Gerven, 'The Genesis of EEA Law and the Principles of Primacy and Direct Effect' (1992) 16 Fordham International Law Journal 955.

112 Sevón (n 71) 732.
} 


\section{LIST OF REFERENCES}

Bårdsen A, 'Fundamental Rights in EEA Law - The Perspective of a National Supreme Court Justice' (Spring Seminar, EFTA Court, Luxembourg, 12 June 2015).

Barnard C, 'Reciprocity, Homogeneity and Loyal Cooperation: Dealing with Recalcitrant National Courts?' in EFTA Court (ed), The EE $A$ and the EFTA Court: Decentred Integration (Hart Publishing 2014).

DOI: http://doi.org/10.5040/9781474201216.ch-014.

Baudenbacher C, 'If Not EEA State Liability, Then What? Reflections Ten Years after the EFTA Court's Sveinbjörnsdóttir Ruling' (2009) 10 Chicago Journal of International Law 333.

Baudenbacher C, Judicial Independence: Memoirs of a European Judge (Springer 2019).

DOI: http://doi.org/10.1007/978-3-030-02308-9.

Bekkedal T, 'Understanding the Nature of the EEA Agreement: On the Direct Applicability of Regulations’ (2020) 57 Common Market Law Review 773.

Björgvinsson DT, 'On the Interplay between EC Law, EEA Law and the European Convention on Human Rights' in Martin Johansson, Nils Wahl and Ulf Bernitz (eds), Liber Amicorum in Honour of Sven Norberg: A European for All Seasons (Bruylant 2006).

Björgvinsson DT, 'The EEA Agreement and Fundamental Rights' in Lucius Caflisch and others (eds), Liber Amicorum Luzius Wildhaber: Human Rights - Strasbourg Views, Droits de l'bomme - Regards de Strasbourg (NP Engel Verlag 2007).

Butler G, 'Independence of Non-Judicial Bodies and Orders for a Preliminary Reference to the Court of Justice' (2020) 45 European Law Review 870.

Butler, G. 'Mind the (Homogeneity) Gap: Independence of Referring Bodies Requesting Advisory Opinions from the EFTA Court' (2020) 44 Fordham International Law Journal.

Curtin D, 'The Province of Government: Delimiting the Direct Effect of Directives in the Common Law Context' (1990) 15 European Law Review 195.

Fenger N, Sánchez Rydelski M and Van Stiphout T, European Free Trade Association (EFTA) and European Economic Area (EEA) (Kluwer Law International 2012).

Frantziou E, '(Most of) the Charter of Fundamental Rights Is Horizontally Applicable: ECJ 6 November 2018, Joined Cases C-569/16 and C-570/16, Bauer et Al' (2019) 15 European Constitutional Law Review 306.

DOI: https://doi.org/10.1017/S1574019619000166. 
Frantziou E, The Horizontal Effect of Fundamental Rights in the European Union: A Constitutional Analysis (Oxford University Press 2019).

Fredriksen HH, 'The EFTA Court and the Principle of State Liability: Protecting the Jewel in the Crown' in EFTA Court (ed), The EEA and the EFTA Court: Decentred Integration (Hart Publishing 2014).

DOI: http://doi.org/10.5040/9781474201216.ch-026.

Fredriksen $\mathrm{HH}$ and Johansen SØ, 'The EEA Agreement as a Jack-in-the-Box in the Relationship between the CJEU and the ECtHR?' [2020] European Papers.

Groussot X, General Principles of Community Law (Europa Law Publishing 2006).

Groussot X, 'Direct Horizontal Effect in EU Law after Lisbon - The Impact of the EU Charter of Fundamental Rights on Private Parties' in Patrik Lindskoug and others (eds), Essays in Honour of Michael Bogdan (Juristförlaget 2013).

Leczykiewicz D, 'Horizontal Application of the Charter of Fundamental Rights' (2013) 38 European Law Review 479.

Magnússon S, 'Efficient Judicial Protection of EEA Rights in the EFTA Pillar - Different Role for the National Judge?' in EFTA Court (ed), The EE $A$ and the EFTA Court: Decentred Integration (Hart Publishing 2014).

DOI: http://doi.org/10.5040/9781474201216.ch-011.

Méndez Pinedo ME, EC and EEA Law: A Comparative Study of the Effectiveness of European Law (Europa Law Publishing 2009).

Muir E, 'The Horizontal Effects of Charter Rights given Expression to in EU Legislation, from Mangold to Bauer' (2020) 13 Review of European Administrative Law 185.

Prechal S, 'Remedies After Marshall’ (1990) 27 Common Market Law Review 451.

Prechal S, Directives in European Community Law: A Study of Directives and Their Enforcement in National Courts (Clarendon Press 1995).

Prechal S, 'Member State Liability and Direct Effect: What's the Difference After All?' (2006) 17 European Business Law Review 299.

Schütze R, 'Direct Effects and Indirect Effects of Union Law' in Robert Schütze and Takis Tridimas (eds), Oxford Principles of European Union Law, vol 1: The European Union Legal Order (Oxford University Press 2018). 
Schütze R, European Union Law (Second edition, Cambridge University Press 2018). DOI: https://doi.org/10.1017/9781108555913.

Sevón L, 'The ECJ, the EFTA Court and the national courts of the EFTA countries' in Peter Lødrup and others (eds), Rettsteori og rettsliv: Festskrift til Carsten Smith (Universitetsforlaget 2002).

Spanó R, 'The EFTA Court and Fundamental Rights' (2017) 13 European Constitutional Law Review 475.

DOI: https://doi.org/10.1017/S1574019617000232.

Szpunar M, 'The Authority of EU Law: The Case of Horizontal Application of Fundamental Rights' in Wolfgang Heusel and Jean-Philippe Rageade (eds), The Authority of EU Law: Do We Still Believe in It? (Springer 2019).

DOI: https://doi.org/10.1007/978-3-662-58841-3 10.

Tridimas T, 'Horizontal Effect of Directives: A Missed Opportunity' (1994) 19 European Law Review 621.

Tridimas T, 'Black, White, and Shades of Grey: Horizontality of Directives Revisited' (2001) 21 Yearbook of European Law 327.

DOI: https://doi.org/10.1093/yel/21.1.327.

Tridimas T, The General Principles of EU Law (Second Edition, Oxford University Press 2006).

Tridimas T, 'Horizontal Effect of General Principles: Bold Rulings and Fine Distinctions' in Ulf Bernitz, Xavier Groussot and Felix Schulyok (eds), General Principles of EU Law and European Private Law (Kluwer Law International 2013).

Tridimas T, 'Fundamental Rights, General Principles of EU Law, and the Charter' (2014) 16 Cambridge Yearbook of European Legal Studies 361.

DOI: https://doi.org/10.1017/S1528887000002676.

Van Gerven W, 'The Genesis of EEA Law and the Principles of Primacy and Direct Effect' (1992) 16 Fordham International Law Journal 955.

Van Gerven W, 'The Horizontal Effect of Directive Provisions Revisited: The Reality of Catchwords' in Deirdre Curtin and Tom Heukels (eds), Institutional Dynamics of European Integration: Essays in Honour of Henry G. Schermers, Volume II (Martinus Nijhoff Publishers 1994).

Wahl N, 'Unchartered Waters: Reflection on the Legal Significance of the Charter under EEA Law and Judicial Cross-Fertilisation in the Field of Fundamental Rights' in EFTA Court (ed), The EE $A$ and the EFTA Court: Decentred Integration (Hart Publishing 2014).

DOI: http://doi.org/10.5040/9781474201216.ch-023. 
Walkila S, Horizontal Effect of Fundamental Rights in EU Law (Europa Law Publishing 2016)

Winter JA, 'Direct Applicability and Direct Effect: Two Distinct and Different Concepts in Community Law' (1972) 9 Common Market Law Review 425.

Ziegler KS, Moreno-Lax V and Neuvonen PJ (eds), Research Handbook on General Principles of EU Law (Edward Elgar 2021). 